\title{
ZADAĆE KLJUČNIH KNJIŽNIČARA \\ U MODULU KATALOGIZACIJE INTEGRIRANOG KNJIŽNIČNOG SUSTAVA NACIONALNE I SVEUČILIŠNE KNJIŽNICE U ZAGREBU I VISOKOŠKOLSKIH I ZNANSTVENIH KNJIŽNICA
}

\author{
THE TASKS OF KEY LIBRARIANS \\ IN THE CATALOGUING MODULE OF THE INTEGRATED \\ LIBRARY SYSTEM OF THE NATIONAL AND UNIVERSITY \\ LIBRARY IN ZAGREB AND THE ACADEMIC \\ AND RESEARCH LIBRARIES
}

\begin{abstract}
Anita Marin
Nacionalna i sveučilišna knjižnica u Zagrebu

amarin@nsk.hr

Sonja Pigac

Nacionalna i sveučilišna knjižnica u Zagrebu spigac@nsk.hr
\end{abstract}

UDK / UDC 025.3: 027.7: 027.021

Stručni rad / Professional paper

Primljeno / Received: 30. 3. 2018.

Prihvaćeno / Accepted: 11. 4. 2019.

\section{Sažetak ${ }^{1}$}

Cilj. U članku je predstavljena radionica Ključni knjižničari za modul katalogizacije koja se održala na Stručnom skupu Knjižnični podaci: interoperabilnost, povezivanje i razmjena 28. i 29. studenog 2017. u Nacionalnoj i sveučilišnoj knjižnici u Zagrebu.

Rad je prezentiran na skupu Knjižnični podaci: interoperabilnost, povezivanje i razmjena, održanom u okviru 2. Konferencije korisnika Integriranog knjižničnog sustava Nacionalne i sveučilišne knjižnice i knjižnica iz sustava znanosti i visokog obrazovanja (Zagreb, 28.-29. 11. 2017.).

Vjesnik bibliotekara Hrvatske 62, 1(2019), 363-382

ISSN 0507-1925

(c) VBH 2018. 
Osnovne zadaće ključnih knjižničara jesu: stručna podrška redovnom radu knjižnica u sustavu, testiranje novih funkcionalnosti modula, praćenje i kontrola rada sustava temeljeni na izvještajima o radu, testiranje i analiza rada servisnih izvještaja na razini cijelog sustava, suradnja sa savjetnikom za integrirani knjižnični sustav, redaktorima baza, administratorom sustava, sistemskim i ključnim knjižničarima zaduženim za administrativno upravljanje sustavom te pružanje pomoći i edukacija sudionika u sustavu.

Metodologija. Polazeći od osnovnih aspekata uloge i rada ključnih knjižničara u okviru Integriranog knjižničnog sustava Nacionalne i sveučilišne knjižnice u Zagrebu te knjižnica iz sustava znanosti i visokog obrazovanja opisan je svaki aspekt rada $\mathrm{u}$ modulu katalogizacije.

Rezultati. Integrirani knjižnični sustav temelji se na primjeni zajedničkog programskog sustava Aleph, formata MARC 21, središnje normativne kontrole i nacionalnog predmetnog sustava. Nacionalna i sveučilišna knjižnica u Zagrebu, kao središnja knjižnica u sustavu, osigurava stručnu, tehničku i administrativnu podršku u radu zajedničkog informacijsko-knjižničnog sustava. Ključni knjižničari u modulu katalogizacije održavaju redovite tečajeve Osnove modula Katalogizacija, kao i demonstracijske vježbe. Knjižnice u sustavu zajednički koriste normativnu bazu Nacionalne i sveučilišne knjižnice i predloške za rad, dok se kataložni zapisi preuzimaju prema potrebi iz baza u sustavu ili se izrađuju novi. Putem Sustava za podršku https://iks.nsk.hr/podrska/ šalju se prijavnice u kojima se navode poteškoće s kojima se susreću knjižničari, a rješavaju ih redaktori, ključni i sistemski knjižničari.

Praktična primjena. Rezultati ovoga rada mogu pomoći knjižničarima iz knjižnica članica Integriranog sustava u njihovu svakodnevnom radu.

Originalnost. Široj se knjižničnoj zajednici nastoji približiti termin ključni knjižničari te njihova uloga u razvoju struke.

Ključne riječi: Aleph, integrirani knjižnični sustav, katalogizacija, ključni knjižničar

\begin{abstract}
Purpose. The paper presents a workshop titled Key Librarians for Cataloguing Module held at the Conference „Library Data: Interoperability, Connectivity, and Exchange“, held on 28th and 29th November 2017 at the National and University Library in Zagreb. The basic tasks of key librarians are: expert support to regular library work of the libraries in the network, testing new functionalities of system modules, monitoring and control of library system based on work reports, testing and analysis of service reports at the system level, collaboration with the integrated library system consultant, the base editors, system administrators, system and key librarians in charge of administrative system management, and assisting and educating participants in the system.
\end{abstract}

Approach. Starting from the basic aspects of the role and work of key librarians within the Integrated Library System of the National and University Library in Zagreb 
and the libraries from the science and higher education system, every aspect of the work in the cataloging module is described.

Findings. The integrated library system is based on the application of the common programming system Aleph, MARC 21 format, central authority control and national subject headings system. The National and University Library in Zagreb, being the central library of the system, provides professional, technical, and administrative support in the work of the common information and library system. The key librarians of the cataloging module conduct regular courses in the Basics of the Cataloging Module as well as practical exercises (demonstration). Libraries in the integrated library system commonly use the National and University Library authority database and templates, while the catalog bibliographic records are retrieved and downloaded as needed from the system's bases or are created from scratch. The librarians fill up the forms in which they describe the encountered difficulties and send them through the support system, https://iks.nsk.hr/podrska/, which are then resolved by the editors, or key and system librarians.

Practical use. The results of this paper can help librarians who work in the Integrated system member libraries in their day-to-day work.

Originality/Value. The article strives to bring closer the term key librarians and explain their role in the development of the profession to wider library community.

Keywords: Aleph, cataloguing, integrated library system, key librarian

\section{Uvod}

Integrirani knjižnični sustav Nacionalne i sveučilišne knjižnice u Zagrebu te visokoškolskih i znanstvenih knjižnica Republike Hrvatske naziv je mreže knjižnica iz sustava znanosti i visokog obrazovanja Republike Hrvatske koje koriste integrirani knjižnični program Aleph. Danas su u sustav, uz Nacionalnu i sveučilišnu knjižnicu, uključene 42 visokoškolske i znanstvene knjižnice s Hrvatskog katoličkog sveučilišta (1), Sveučilišta u Zagrebu (28), Znanstvenih instituta (11) i Veleučilišta u Karlovcu i Velikoj Gorici (2). ${ }^{2}$ Nacionalna i sveučilišna knjižnica u Zagrebu organizacijski, tehnički i administrativno podržava rad integriranog knjižničnog sustava koji se temelji na primjeni korištenja knjižničnog programa Aleph (ExLibris ${ }^{3}$ ) za sve knjižnice iz sustava, formatu MARC 21, središnjem normativnom nadzoru i nacionalnom predmetnom sustavu.

\footnotetext{
2 Machala, D. Analiza korištenja i prihvaćanja Integriranog knjižničnog sustava Nacionalne i sveučilišne knjižnice u Zagrebu te visokoškolskih i znanstvenih knjižnica Republike Hrvatske. // Vjesnik bibliotekara Hrvatske 61, 1(2018), str. 435. DOI: https://doi.org/10.30754/vbh.61.1.631.

3 Više na Aleph: integrated library system. [citirano: 2018-03-22]. Dostupno na: https://www. exlibrisgroup.com/products/aleph-integrated-library-system/.
} 
Ciljevi stvaranja integriranog knjižničnog sustava, koji čine spomenute knjižnice, jesu „povećanje kakvoće usluga knjižnica i dostupnost svih podataka svim korisnicima, povećanje kakvoće i olakšavanje rada knjižničara te međusobna povezanost i standardiziranost knjižničnih podataka“. ${ }^{4}$ Sredinom 2010. godine NSK je dovršila proces implementacije integriranog knjižničnog sustava Aleph500 v.20. S obzirom na to da je već ranije prepoznata potreba stvaranja zajedničkog integriranog knjižničnog sustava na razini Sveučilišta i Nacionalne i sveučilišne knjižnice u Zagrebu, godine 2009. potpisivanjem Ugovora između navedenih strana o suradnji u implementaciji knjižničnog programa stvoreni su i formalno-pravni temelji budućoj suradnji. ${ }^{5}$

U integrirani knjižnični sustav Aleph (http://skupnikatalog.nsk.hr) objedinjeni su katalozi Nacionalne i sveučilišne knjižnice i katalozi knjižnica članica sustava. Katalog Nacionalne i sveučilišne knjižnice u Zagrebu ${ }^{6}$ sadrži zapise za knjižnu i drugu vrstu građe koja se nalazi u fondu prikupljena obveznim primjerkom, kupnjom, darom i zamjenom. Osim zapisa za hrvatsku i stranu knjižničnu građu iz općeg fonda NSK, u katalogu se nalaze i zapisi za građu iz zbirki rukopisa i starih knjiga, muzikalija i audiomaterijala, zemljovida i atlasa te grafičke zbirke. Katalozi knjižnica iz sustava ${ }^{7}$ omogućuju pristup knjižničnim katalozima pojedinih visokoškolskih knjižnica sastavnica Sveučilišta u Zagrebu, znanstvenih knjižnica i knjižnica visokih učilišta na području Grada Zagreba i Zagrebačke županije. U prvoj fazi realizacije skupnog kataloga uključene su Nacionalna i sveučilišna knjižnica u Zagrebu te knjižnice iz sustava Zagrebačkog sveučilišta (ZAG) koje koriste program Aleph i format MARC 21, dok su u drugoj fazi uključeni katalozi Filozofskog fakulteta u Zagrebu i Fakulteta elektrotehnike i računarstva koji koriste program Koha. Kasnije su se priključile i ostale knjižnice neovisno o tome koji program upotrebljavaju i koji format UNIMARC koriste. ${ }^{8}$ Osim zapisa iz bibliografskih baza NSK01 i ZAG01, u integrirani skupni katalog bit će uključeni

\footnotetext{
4 Machala, D. Hrvatski skupni katalog Nacionalne i sveučilišne knjižnice u Zagrebu te knjižnica iz sustava Znanosti i visokog obrazovanja: problemska pitanja interoperabilnosti. // Vjesnik bibliotekara Hrvatske 59, 1-2(2016), str. 477. DOI: https://doi.org/10.30754/vbh.61.1.636.

5 Machala, D.; L. Machala. Implementacija integriranog knjižničnog sustava Aleph u Nacionalnoj i sveučilišnoj knjižnici u Zagrebu i knjižnicama sastavnica Sveučilišta u Zagrebu i znanstvenih instituta: utvrđenja implementacijskog procesa. // Knjižnice: kamo i kako dalje? : zbornik radova / 12. dani specijalnih i visokoškolskih knjižnica, Opatija, 11.-14. svibnja 2011.; uredile Alisa Martek i Elizabeta Rybak Budić. Zagreb: Hrvatsko knjižničarsko društvo, 2013. Str. 334.

6 Knjžnični katalog / Nacionalna i sveučilišna knjižnica u Zagrebu. [citirano: 2018-04-10]. Dostupno na: http://katalog.nsk.hr/.

7 Knjižnični katalog / Sveučilište u Zagrebu. [citirano: 2018-04-10]. Dostupno na: http://zag. nsk.hr.

8 Machala, D. Skupni katalog knjižnica iz sustava znanosti i visokoga obrazovanja Republike Hrvatske. // Glas NSK 4, 14(2018), str. 25. Dostupno i na: http://www.nsk.hr/wp-content/uploads/2018/03/Broj-14-jesen-zima-2017.-Glas@NSK.pdf.
} 
i podaci iz Nacionalnog repozitorija završnih i diplomskih radova (ZIR) $)^{9}$, Nacionalnog repozitorija disertacija i znanstvenih magistarskih radova $(D R)^{10}$ koji se temelje na infrastrukturi Dabar $(\mathrm{Srce})^{11} \mathrm{i}$ središnji indeks baza podataka znanstvenih izvora. ${ }^{12} \mathrm{U}$ zadnjoj fazi bit će objedinjeni drugi skupni katalozi i katalozi ostalih sveučilišnih knjižnica u Hrvatskoj. ${ }^{13}$

Osim bibliografskih baza, integrirani knjižnični sustav sadrži i jedinstvenu normativnu bazu (NSK 10) za sve korisnike sustava koja omogućuje pretraživanje predmetnih i autorskih odrednica izrađenih u Nacionalnoj i sveučilišnoj knjižnici, baze podataka o nabavi, cirkulaciji i korisnicima (ZAG50, NSK50), baze podataka o posjedovanju gdje su sadržani podaci o lokaciji i primjercima (ZAG60, NSK60), a u planu je i izrada baza međuknjižnične posudbe (NSK20) te ispitne literature (NSK30, ZAG30). ${ }^{14}$

Funkcija ključnih knjižničara za pojedinačne module specifičnost je programskih sustava tvrtke Endeavor, odnosno ExLibris, nastala kao rezultat potrebe da knjižnični stručnjaci sudjeluju i pomognu tehničkom osoblju prilikom implementacije knjižničnih sustava novije generacije i migracije podataka iz postojećih sustava u nove, primjerice u NSK prelaskom iz sustava Voyager u Aleph ili u budućnosti planiranog prelaska iz Alepha u Almu. ${ }^{15}$ Uspostavom integriranog knjižničnog sustava Aleph bilo je nužno redefinirati dosadašnji model knjižničnog osoblja ${ }^{16}$, u skladu s čim je preuzeta nova funkcija ključnog knjižničara. Za razliku od ključnog knjižničara, knjižničnoj djelatnosti otprije je bila poznata i nužna uloga sistemskog knjižničara kao stručnjaka koji poznaje rad s računalima te općenito upravlja informacijskim resursima unutar knjižnice. Definicija sistemskog knjižničara u literaturi ima više, a njegove su zadaće često ovisile o vrsti, veličini, proračunu i potrebama knjižnice u kojoj radi, kao i interpretacije i očekivanja o

9 Nacionalni repozitorij završnih i diplomskih radova ZIR. [citirano: 2018-04-10]. Dostupno na: https://zir.nsk.hr/.

10 Nacionalni repozitorij disertacija i znanstvenih magistarskih radova. [citirano: 2018-04-10]. Dostupno na: https://dr.nsk.hr/.

11 Digitalni akademski arhivi i repozitoriji. [citirano: 2018-04-10]. Dostupno na: https://dabar. srce.hr/.

12 Smjernice za izradu skupnog kataloga Integriranog knjižničnog sustava Nacionalne i sveučilišne knjižnice u Zagrebu, visokoškolskih i znanstvenih knjižnica Republike Hrvatske. Zagreb: Nacionalna i sveučilišna knjižnica, 2016. [citirano: 2018-03-28]. Dostupno na: http://buki.nsk.hr/ wp-content/uploads/2017/03/Smjernice-za-izradu-skupnog-kataloga_2016.docx.

13 Machala, D. Skupni. Nav. djelo, str. 25.

14 Smjernice. Nav. djelo.

15 Usp. Fu. P.; J. Carmen. Migration to Alma/Primo: a case study of Central Washington University. // Chinese Librarianship: an International Electronic Journal 40(2015). [citirano 2018-11-25]. Dostupno na: http://www.iclc.us/cliej/cl40FC.pdf.

16 Fu, P.; M. Fitzgerald. A comparative analysis of the effect of the integrated library sistem on staffing models in academic libraries. // Information Technology \& Libraries 32, 3(2013), 47-58. [citirano 2018-11-25]. Dostupno na: https://ejournals.bc.edu/ojs/index.php/ital/article/view/3388. 
tome što bi točno trebao biti njegov djelokrug rada. No gotovo svaki opis poslova koji se očekuju od sistemskog knjižničara podrazumijeva ne samo razumijevanje knjižnične djelatnosti i informatičke tehnologije već i stavljanje tih dvaju polja u međusobni kontekst.

Razlike u poimanju sistemskog knjižničarstva vjerojatno najbolje oslikava činjenica da neki smatraju kako sistemske poslove ne trebaju obavljati knjižničari, već tehničko osoblje. ${ }^{17} \mathrm{U}$ idealnim uvjetima sistemski bi knjižničari trebali dobro poznavati poslove svih vrsta knjižnica, no to često nije slučaj. Iako oni razmjerno dobro poznaju struku, uvijek je potrebno i dodatno znanje koje se stječe usput u radnom procesu. U najkonstruktivnijem okruženju dolazi do međuovisnosti knjižničnog osoblja ${ }^{18}$, u skladu s čim je u integrirani knjižnični sustav uvedena i uloga ključnih knjižničara pojedinih modula koji služe kao spona između ostalih knjižničnih djelatnika i sistemskih knjižničara.

Integrirani se knjižnični program Aleph sastoji od nekoliko modula (Katalogizacija, Cirkulacija i Nabava/Serijska građa ${ }^{19}$ ) koji su međusobno povezani omogućujući tako neprekinut i konzistentan rad u svim fazama radnog procesa. Za svaki pojedinačni modul postoje ključni knjižničari čije su glavne zadaće definirane sljedećim opsegom poslova:

- stručna podrška redovnom radu knjižnica u sustavu

- pružanje pomoći i edukacija sudionika u sustavu

- testiranje novih funkcionalnosti modula;

- praćenje i kontrola rada sustava temeljeni na izvještajima o radu

- testiranje i analiza rada servisnih izvještaja na razini cijelog sustava;

suradnja sa savjetnikom za integrirani knjižnični sustav, redaktorima baza, administratorom sustava, sistemskim i ključnim knjižničarima zaduženim za administrativno upravljanje sustavom. ${ }^{20}$

\section{Povjerenstvo za knjižnični sustav u NSK}

S obzirom na to da je Nacionalna i sveučilišna knjižnica u Zagrebu središnja knjižnica sustava, zadaća joj je osigurati stručnu, tehničku i administrativnu podršku radu zajedničkog informacijsko-knjižničnog sustava. Imajući u vidu učinkovitije ispunjavanje svoje uloge, 2015. godine imenovano je Povjerenstvo za

\footnotetext{
17 Wilson, T. C. Sistemski knjižničar: oblikovanje uloga, definiranje vještina. Zagreb: Hrvatsko knjižničarsko društvo, 2006. Str. 4.

18 Isto. Str. 10.

19 Verzija Aleph 22 uključuje i modul međuknjižnične posudbe.

20 Odluka o imenovanju ključnih knjižničara. Zagreb, 2016. (Klasa: 080-01/1 6-01/04, ur. broj: 474-13-01-16-2).
} 
knjižnični sustav u NSK. ${ }^{21}$ U rad Povjerenstva uključeni su ključni knjižničari svih modula, sistemski knjižničari i analitičar, redaktori baza, koordinatori radnih procesa te savjetnica za knjižnični informacijski sustav. Povjerenstvo se bavi razvojnim aktivnostima, planiranjem, organizacijom i implementacijom funkcionalnih dorada integriranog knjižničnog sustava te prati novosti u primjeni informacijske i telekomunikacijske tehnologije u razvoju suvremenih digitalnih knjižničnih usluga. Jedna je od zadaća i uočavanje problema knjižničnog programa Aleph, odnosno mjesta na kojima ga je potrebno nadograditi radi poboljšanja i pružanja bolje usluge stavljanjem u funkciju mogućnosti programa koje dosad nisu bile aktivne. Također, zadaća je Povjerenstva i razmatranje zamjene postojećeg knjižničnog sustava nekim novim, analizirajući njegove performanse. ${ }^{22}$

Povjerenstvo (posebno ključni knjižničari svih modula) zajedno s djelatnicima svih odjela radi na testiranju novih funkcionalnosti integriranoga knjižničnog programa Aleph, kao i na uspostavi skupnoga kataloga integriranoga knjižničnog sustava NSK i knjižnica iz sustava znanosti i visokoga obrazovanja ${ }^{23}$, što posebice pridonosi ostvarenju strateškog cilja NSK u pružanju potpore razvoju Knjižničnog sustava Sveučilišta u Zagrebu. ${ }^{24}$

Jedan je od ciljeva Povjerenstva za knjižnični informacijski sustav i redovito prikupljanje i analiza podataka o stanju standardizacije, automatizacije i informatizacije poslovanja hrvatskih knjižnica radi racionalizacije njihova poslovanja. Knjižnice trebaju pratiti novosti u globalnoj knjižničnoj zajednici i u svoje poslovanje uvoditi nove knjižnične programe te pratiti razvoj novih usluga temeljenih na knjižničnim podacima i njihovoj razmjeni. ${ }^{25}$

Zadaća je ključnih knjižničara u modulu katalogizacije sustavan bibliografski nadzor usklađene primjene nacionalnog kataložnog pravilnika ${ }^{26}$, zajedničkih pravila za rad u integriranom knjižničnom sustavu, općih smjernica za deskriptivan opis, sustavan redakcijski nadzor te trajno osuvremenjivanje postupka deduplika-

21 Odluka o imenovanju Povjerenstva za knjižnični sustav u NSK. Zagreb, 1015. (Klasa: 65001/15-01/1, ur. broj: 474-13-01-15-10).

22 Isto.

23 Izvješće o radu za 2016. godinu. Zagreb: Nacionalna i sveučilišna knjižnica, 2017. [citirano: 2018-03-19]. Dostupno na: http://www.nsk.hr/wp-content/uploads/2017/07/Izvje\%C5\%A1\%C4\%87e-o-radu-NSK-za-2016.-godinu.pdf.

24 Strategija Nacionalne i sveučilišne knjižnice u Zagrebu 2016.-2020. Zagreb: Nacionalna i sveučilišna knjižnica, 2016. [citirano: 2018-03-19]. Dostupno na: http://www.nsk.hr/wp-content/ uploads/2012/01/Strategija-NSK-2016.-2020..pdf.

${ }_{25}$ Mrežni portal Knjižnični informacijski sustav Nacionalne i sveučilišne knjižnice u Zagrebu BUKI. [citirano: 2018-03-30]. Dostupno na: http://buki.nsk.hr/automatizacija/.

26 Verona, E. Pravilnik i priručnik za izradbu abecednih kataloga. Zagreb: Hrvatsko bibliotekarsko društvo, 1970-1983. Dio 1: Odrednice i redalice. 1970. ; Verona, E. Pravilnik i priručnik za izradbu abecednih kataloga. Zagreb: Hrvatsko bibliotekarsko društvo, 1983-1986. Dio 1: Odrednice i redalice. 2. izmijenjeno izd. 1986. 
cije zapisa. U skoro se vrijeme očekuje primjena novog nacionalnog pravilnika ${ }^{27}$ za knjižnice, arhive i muzeje kako bi bibliografski zapisi mogli udovoljiti novim načinima objavljivanja i distribuiranja sadržaja te načinu traženja informacija $u$ okviru semantičkog weba. ${ }^{28}$ Ključni knjižničari u modulu katalogizacije uključeni su u Radnu grupu za format MARC 21/B koja se bavi praćenjem promjena formata i nadzorom nad ujednačenom primjenom bibliografskih podataka u okviru integriranog knjižničnog sustava te Radnu grupu za katalogizaciju koja usklađuje primjenu formata s važećim pravilima i standardima za opis svih vrsta knjižnične građe. Ključni knjižničari bit će uključeni u buduću prilagodbu formata MARC 21 prema novom pravilniku.

\section{Hrvatski nacionalni skupni katalog: testiranje funkcionalnosti i uspostava}

Izrada skupnog kataloga integriranog knjižničnog sustava Nacionalne i sveučilišne knjižnice u Zagrebu, visokoškolskih i znanstvenih knjižnica sastavni je dio programa uspostave nacionalnog skupnog kataloga, što je ujedno prema Statutu i jedna od temeljnih zadaća Nacionalne i sveučilišne knjižnice. ${ }^{29,30}$ Godine 2016. Nacionalna i sveučilišna knjižnica pokrenula je, na temelju aplikacije otvorenog koda za objedinjeno pretraživanje distribuiranih knjižničnih kataloga i za prikaz različitih formata i podataka VuFind ${ }^{31}$, izradu Skupnoga kataloga koja je provedena u dva koraka. Prvi korak obuhvatio je upoznavanje sa samim sustavom i njegovom primjenom u drugim knjižnicama ${ }^{32}$, dok je drugi korak obuhvatio instalaciju testne inačice na poslužitelju NSK, oblikovanje baze Sorl te migraciju i mapiranje bibliografskih podataka iz sustava Aleph. ${ }^{33}$

27 Pravilnik za opis i pristup građi u arhivima, knjižnicama i muzejima [citirano: 2018-03-26]. Dostupno na: http://nkp.nsk.hr/.

28 Usp. Vukadin, A. Novi pravilnik za katalogizaciju u kontekstu međunarodnih načela standarda. // Vjesnik bibliotekara Hrvatske 59, 1-2(2016), 49-71. [citirano: 2018-11-22]. Dostupno i na: https://www.hkdrustvo.hr/vjesnik-bibliotekara-hrvatske/index.php/vbh/article/view/16.

29 Smjernice. Nav. djelo.

30 Statut Nacionalne i sveučilišne knjižnice u Zagrebu. [citirano: 2018-03-28]. Dostupno na: http://www.nsk.hr/wp-content/uploads/2012/01/Statut-NSK-24_12_2010.pdf.

31 VuFind. [citirano: 2018-03-28]. Dostupno na: https://vufind.org/vufind/.

32 Usp. Machala, L. Integrirani knjižnični sustav Aleph: implementacija na primjerima Sveučilišta u Iowi i visokoškolskih knjižnica u Litvi. // Knjižnice: kamo i kako dalje? : knjižnice i očuvanje kulturne baštine, knjižnice bez granica: digitalni repozitoriji, knjižnični softveri: zbornik radova / 11. dani specijalnih i visokoškolskih knjižnica, Opatija, 1.-4 travnja 2009.; uredile Tamara Krajna i Alisa Martek. Zagreb: Hrvatsko knjižničarsko društvo, 2010. Str. 231-244.

33 Orešković, M. VuFind - discovery servis otvorena koda kao programsko rješenje za uspostavu nacionalnoga skupnog kataloga knjižnica iz sustava znanosti i visokoga obrazovanja Republike Hrvatske. // Glas NSK 4, 14(2018), str. 29. Dostupno i na: http://www.nsk.hr/wp-content/uploads/2018/03/Broj-14-jesen-zima-2017.-Glas@NSK.pdf. 
VuFind omogućuje filtriranje rezultata pretraživanja pomoću facetne navigacije, pruža informacije o dostupnosti i raspoloživosti primjeraka za posudbu u realnome vremenu, poveznice na cjeloviti tekst ukoliko postoji njegova elektronička inačica, kao i na vanjske izvore (npr. biografski podaci o autoru s Wikipedije, ovitak knjige s knjižare Amazon ili, ako postoji, inačica knjige u sustavu poput Google knjiga).$^{34}$ Prikaz rezultata pretraživanja zadovoljava i uvjete za funkcionalnost bibliografskih zapisa (model FRBR, odnosno LRM od 2017. godine) okupljajući ostala izdanja tražene jedinice građe, radove istog autora na različitim jezicima, u raznim pojavnim oblicima i sl.

Povećanje kakvoće i olakšavanje rada knjižničara ostvareno je prvenstveno objedinjavanjem podataka o fondovima pojedinačnih knjižnica, razmjenom kataložnih zapisa u različitim MARC-formatima nastalih decentraliziranom i distribuiranom obradom te primjenom bibliografskog i normativnog nadzora i distribuiranog predmetnog sustava. Zajednička pravila za rad u integriranom knjižničnom sustavu te provođenje sustavnog redakcijskog nadzora nad primjenom standarda i formata temeljne su pretpostavke za ostvarenje međusobne povezanosti i transparentnosti podataka u knjižnici. ${ }^{35}$

Jedna od poteškoća prilikom izgradnje skupnog kataloga bio je prikaz višestrukih zapisa za istu jedinicu građe. Kako bi se racionalizirao prikaz rezultata pretraživanja u skupnom katalogu, provedena je deduplikacija zapisa u 17 koraka za koju je korišten finski alat RecordManager. ${ }^{36}$ Testiranje deduplikacije pokazalo je brojne slabosti u kvaliteti zapisa te ukazalo na potrebu veće ujednačenosti kataložne prakse. Različitost uporabe ili nepridržavanje knjižničnih standarda upravo u sustavima poput skupnog kataloga dolaze do izražaja. Zadaće su ključnog knjižničara u skupnom katalogu nadzor svih vrsta zapisa, njihov ispravak i prikaz. Neke od nepravilnosti i poteškoća o kojima treba voditi računa jesu i neujednačeni zapisi o posjedovanju ili nepostojanje zapisa o posjedovanju, prikaz dijakritika (npr., Photographie a rienne / $\mathrm{r}$ dacteur Pilote R. Chevallier) ili pisanje odrednica (npr., Autor THEATRES DES CHAMPS-ELYSEES).

Web-prikaz i njegova funkcionalnost također su u domeni poslova ključnog knjižničara koji se skrbi o prikazu različitih vrsta građe, redanju rezultata pretraživanja, prikazu proširenog zapisa, međusobnih veza između zapisa, lokacije, odnosno zapisa o posjedovanju jedinica građe i sl. Slike 1-3 prikazuju zapise o posjedovanju i primjercima u OPAC-u izrađene u tri različite knjižnice i njihove različite prakse navođenja opisa sveščića serijskih jedinica građe - dok prva dva primjera nemaju formiranu zbirku, već navode signaturu, posljednji primjer prikazuje suprotnu praksu.

\footnotetext{
34 Isto, str. 31.

35 Smjernice. Nav. djelo, str. 6.

36 Repositories of the National Library of Finland. RecordManager. [citirano: 2018-03-29]. Dostupno na: https://github.com/NatLibFi/RecordManager.
} 
Prethodni zapis

Prosiriti God. 28., br. 3 (1996)

Prosiriti God. 29., br. 2 (1997)

30 , br. $2(1998)$

Proviriti God. 31., br. 1 (1999)

Prosiriti God. 31., br. 2 (1999) Prethodni zapis

Status primjerka
Pasudba
Posudba
Pasudba
Posudba
Posudba

Vratiti do datuma:

Na polici

Na polici

Na polici

OČkuie se $13 / 03 / 15$

Očekuje se 13/03/15

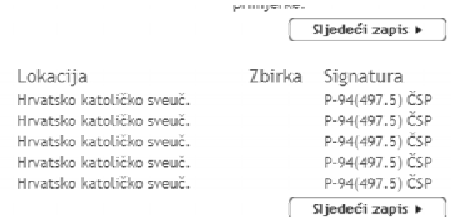

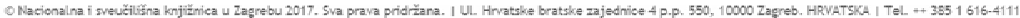

Slika 1. Web-prikaz zapisa o posjedovanju i jedinicama građe bez zbirke - Hrvatsko katoličko sveučilište
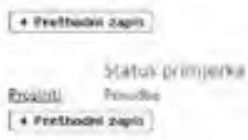

Watier do catuma: ine pola

(cotacia

thedtabi nablet ar bevilen

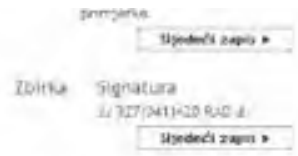

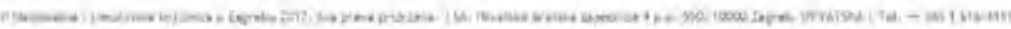

Slika 2. Web-prikaz zapisa o posjedovanju i jedinicama građe bez zbirke - Hrvatski institut za povijest

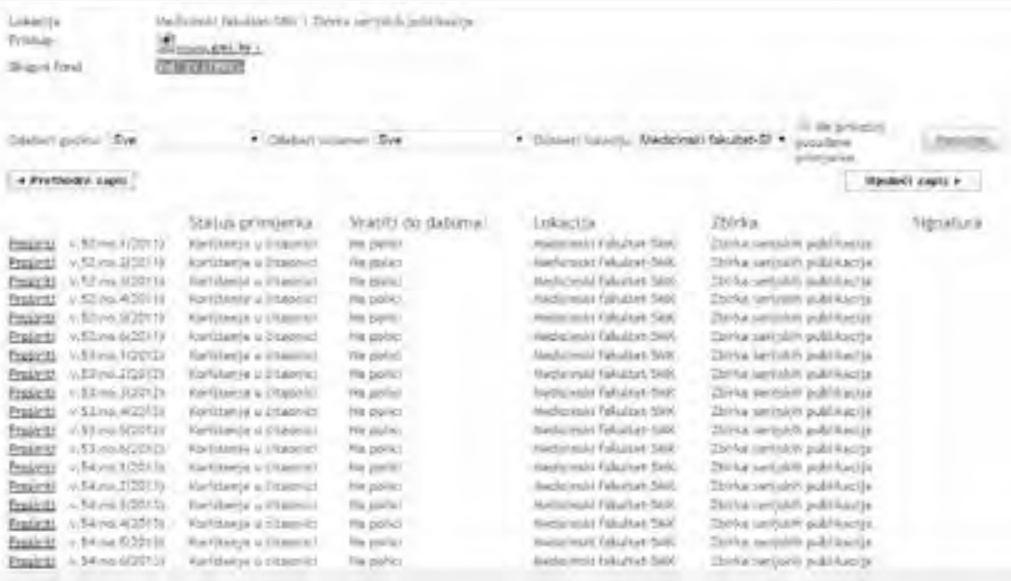

Slika 3. Web-prikaz zapisa o posjedovanju i jedinicama građe bez signature - Medicinski fakultet u Zagrebu

Uz ključne knjižničare, funkcionalnost skupnog katalog testirali su i knjižničari NSK koji rade s različitim vrstama građe, kao i knjižničari iz članica sustava. 


\section{Stručna podrška redovnom radu knjižnica u sustavu}

$\mathrm{Na}$ adresi Integriranog knjižničnog sustava ${ }^{37}$ nalaze se informacije vezane uz razvojne aktivnosti, kao i novosti o primjeni informacijske i telekomunikacijske tehnologije u razvoju suvremenih digitalnih knjižničnih usluga. U razvoju sadržaja portala te razvoju programskih aplikacija sudjeluju članovi Povjerenstva. Kako je već navedeno, sve članice integriranog knjižničnog sustava koriste zajednički program Aleph, format MARC 21, središnju normativnu kontrolu i distribuirani predmetni sustav pa se tako ovdje nalazi i stručna literatura o tim temama (vidi sliku 4). U izborniku Dokumenti ${ }^{38}$ nalaze se upute za katalogizaciju glazbene ${ }^{39}$, kartografske ${ }^{40}$, mrežne $^{41}$, serijske ${ }^{42}$ i omeđene građe ${ }^{43}$, tiskanih doktorskih disertacija te za sadržajnu obradu. ${ }^{44}$ Također su tu i različite smjernice i upute o formatu MARC 21, kratak pregled o programu Aleph te njegovoj nadogradnji i ažuriranju, o tome kako preuzeti zapise iz bibliografske baze Nacionalne i sveučilišne knjižnice, smjernice za otvaranje prijavnice, upute za podršku u Integriranom knjižničnom sustavu (IKS) te postupak validacije i provjere podataka o autorima.

\footnotetext{
37 Integrirani knjižnični sustav. [citirano: 2018-03-22]. Dostupno na: http://iks.nsk.hr/.

38 Integrirani knjižnični sustav. Dokumenti. [citirano: 2018-03-22]. Dostupno na: http://iks.nsk. $\mathrm{hr} /$ dokumenti/.

39 Mihalić, T. Glazbena građa [Elektronička građa]: upute za katalogizaciju u bibliografskom formatu MARC 21. Zagreb: Nacionalna i sveučilišna knjižnica, 2011.

40 Miletić Drder, M.. Kartografska građa [Elektronička građa]: upute za katalogizaciju prema formatu MARC 21, Bibliografski podaci, izdanje 1999., 12. verzija dopuna. Zagreb: Nacionalna i sveučilišna knjižnica, 2011.

41 Buzina, T. Mrežna građa [Elektronička građa]: upute za katalogizaciju prema formatu MARC 21, Bibliografski podaci, izdanje 1999., 12. verzija dopuna. Zagreb: Nacionalna i sveučilišna knjižnica, 2011.

42 Pigac Ljubi, S.; Zajec, J. Tiskane serijske publikacije i druga neomeđena građa [Elektronička građa]: priručnik za katalogizaciju u bibliografskom formatu MARC 21. Zagreb: Nacionalna i sveučilišna knjižnica, 2011.

${ }^{43}$ Hodak, V., Blažević, D. Omeđene publikacije, integrirajuća građa i nakladničke cjeline [Elektronička građa]: priručnik za katalogizaciju u bibliografskom formatu MARC 21. Zagreb: Nacionalna i sveučilišna knjižnica, 2011.

44 Vujić, M. Pregledni zapisi u formatu MARC 21 [Elektronička građa]: upute za katalogizaciju. Zagreb: Nacionalna i sveučilišna knjižnica, 2011.
} 


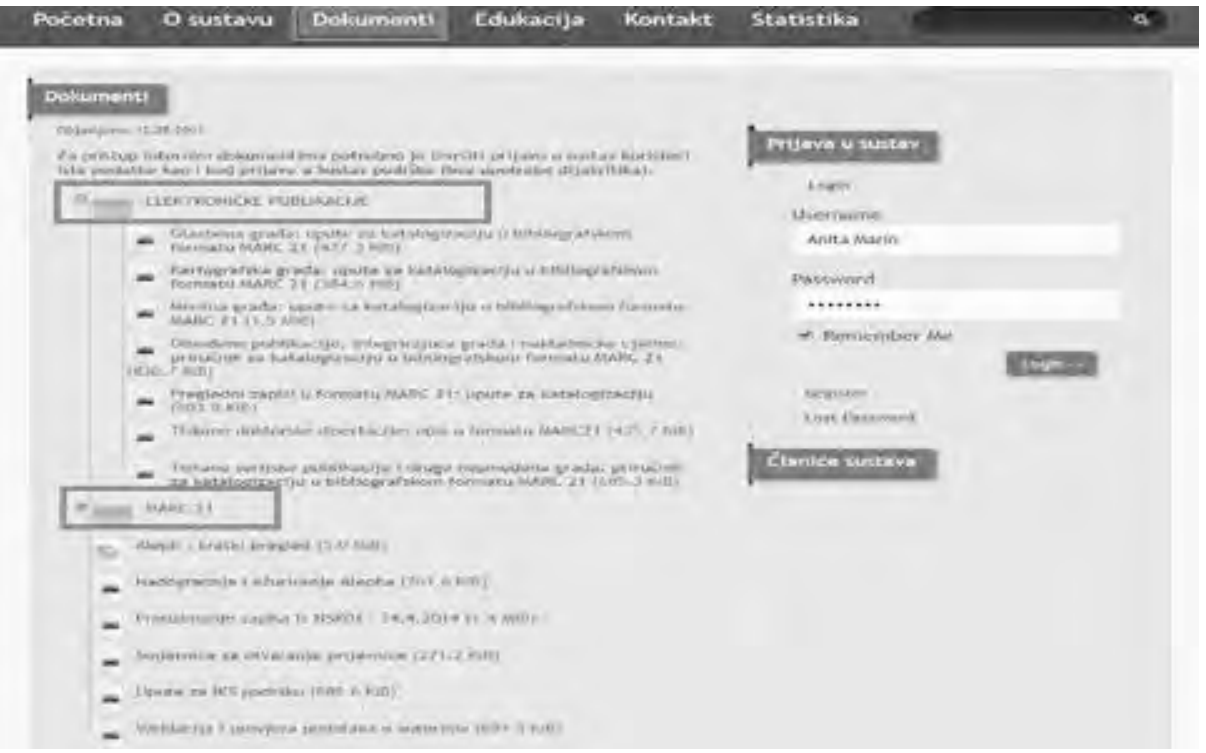

Slika 4. Dokumenti za rad u sustavu IKS

Radi pomoći i ujednačenosti u radu, NSK je uspostavila Sustav za podršku (https://iks.nsk.hr/podrska/) kako bi pružila stručnu i tehničku podršku i ujednačila rad svih članica. Za korištenje sustava za podršku potrebno je izvršiti prijavu u sustav putem korisničkog imena i lozinke.

Kvalitetni i interoperabilni podaci, temeljeni na primjeni standarda i formata, zahtijevaju sustavan redakcijski nadzor koji provode ključni knjižničari, redaktori te koordinatori radnih procesa putem redovitih izvještaja. Kontrola ispravnosti podataka, standardiziran i dogovoren način korištenja formata i nadzor nad procesima rada provodi se pomoću SQL-upita ${ }^{45}$ - najpopularnijeg računalnog jezika za izradu, traženje, ažuriranje i brisanje podataka iz relacijskih baza podataka. Ključni i sistemski knjižničari analizom pogrešaka nastalih u procesu rada razmatraju koje se pogreške mogu automatski ispraviti globalnim izmjenama, a koje će knjižničari ispraviti ili doraditi pojedinačno. Sustav za podršku u okviru portala integriranog knjižničnog sustava osmišljen je tako da knjižničari svih članica koji su ovlašteni za rad u sustavu prijavom mogu poslati upite vezane uz određene probleme koje zaprimaju sistemski knjižničari (vidi sliku 5). Na navedenoj web-adresi nalazi se elektronička prijavnica putem koje knjižničari članica sustava šalju upit definirajući odmah na početku modul uz koji je on vezan, radi li se o problemu/ prijedlogu poboljšanja prikaza na OPAC- $\mathrm{u}^{46}$, ovlastima profila djelatnika u knjiž-

45 Akronim od engl. Structured Query Language.

46 Akronim od engl. Online Public Access Catalogue. 
nici, prijavi tehničke pogreške, instalaciji ili nadogradnji klijenata $\left(\mathrm{GUI}^{47}\right)$, žele li određenu statistiku, izvještaje iz sustava i sl., je li upit vezan uz međuknjižničnu posudbu ili pak nešto drugo. Nakon odabrane opcije navodi se predmet upita te se iz ponuđenog izbornika određuje razina problema (niska (poboljšanje, prijedlog, zahtjev), normalna, visoka i potpuna nemogućnost rada). Ukoliko je potrebno dodatno objašnjenje poteškoće, uz opis zahtjeva moguće je priložiti i datoteku te u konačnici poslati prijavnicu koju rješavaju sistemski knjižničari uz pomoć ključnih knjižničara svih modula.

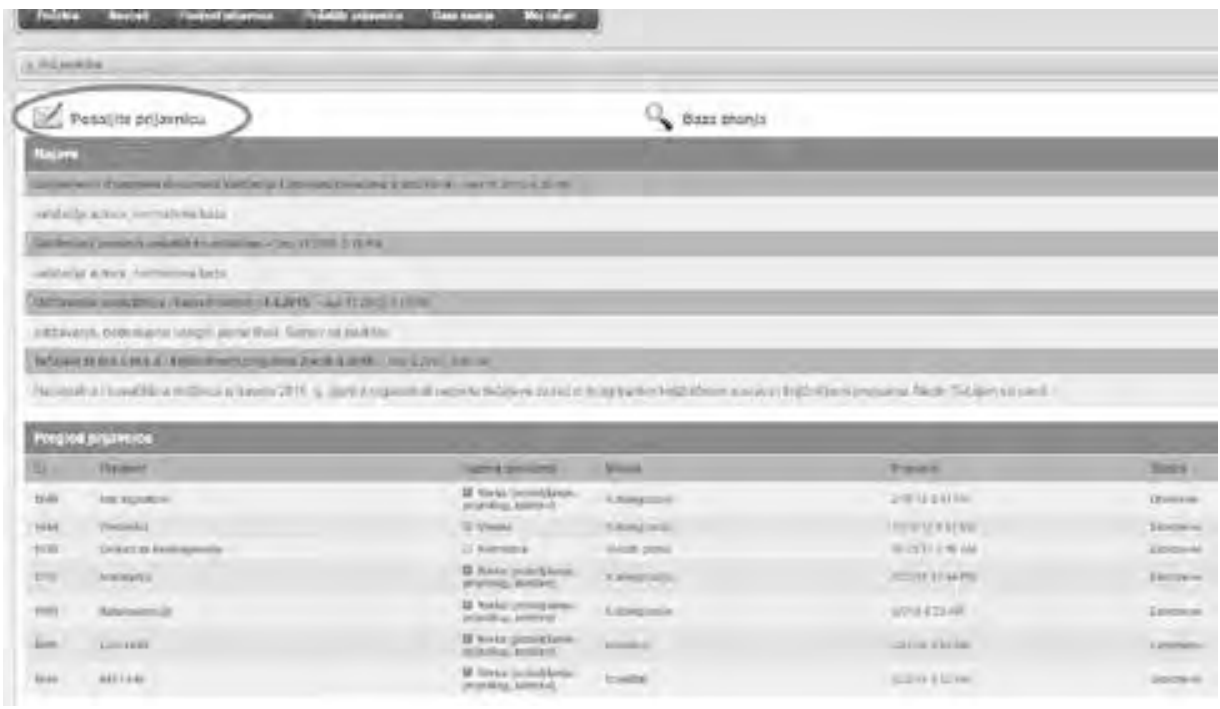

Slika 5. Prijavnica u Sustavu za podršku

Na stranici Sustava za podršku nalazi se i baza znanja gdje se odabirom ključnih riječi može doći do određenih dokumenata. Primjerice odabirom ključne riječi katalogizacija dobije se popis tipkovničkih kratica, mali rječnik nazivlja na engleskom i hrvatskom jeziku te upute o tome kako provjeriti ukupan broj zapisa u ustanovi članici, ukupan broj zapisa koji su konvertirani u sustav i ukupan broj zapisa izrađenih u Alephu.

Ključni knjižničari, redaktori i koordinatori radnih procesa definiraju kriterije za izradu redovitih izvještaja radi kontrole ispravnosti podataka te nadzora nad procesima rada. Cjelovita provedba sustavnog redakcijskog nadzora knjižničnih podataka u bazama integriranog knjižničnog sustava temelj je njegove kvalitetne

47 Akronim od engl. Graphical User Interface. Grafičko korisničko sučelje računalni je program koji omogućuje osobi da komunicira s računalom pomoću grafičkih simbola i vizualnih metafora uz pomoć poruka i obavijesti. 
izgradnje s konačnim ciljem što preciznijeg i bržeg pronalaženja željenih podataka od strane korisnika.

Godine 2016. provedena je anketa o funkcionalnom testiranju i stupnju zadovoljstva korištenja knjižničnim programom Aleph. ${ }^{48}$ Anketni upitnik poslan je na adrese 43 visokoškolske i specijalne knjižnice IKS-a, od čega je na anketu odgovorilo ukupno 28 knjižnica (65\%). Najbolje su ocijenjene kategorije: kvaliteta sustava za podršku (4.1), kvaliteta i dostupnost uputa za rad i priručnika (3.9), mrežni portal IKS (3.7) te komunikacija u sustavu (3.6). Od ponuđenih modula, modul katalogizacije najbolje je ocijenjen (3.5), a zatim slijede s jednakim rezultatom modul cirkulacije i web OPAC (3.2).

Krajem 2017. godine uspostavljen je još jedan portal kao podrška radu NSK na izgradnji i unapređivanju informacijske i znanstvenoistraživačke infrastrukture, ali i cjelokupnog nacionalnog knjižničnog informacijskog sustava, pod nazivom Buki. ${ }^{49}$ Buki sadrži bazu znanja koja okuplja informacije o novostima vezanim uz bibliografski format MARC 21 i načine primjena njegovih polja i potpolja koji su obvezujući za sve članice sustava, a odnose se na bibliografske i normativne zapise. Osim navedenog, portal donosi i podatke o stanju automatizacije poslovanja hrvatskih knjižnica s ciljem poticanja standardizacije i automatizacije poslovanja, razvoja knjižničnih programa i usluga, ali i uvida u stupanj zadovoljstva korištenja knjižničnog programa Aleph..$^{50}$

\section{Edukacija za rad u integriranom knjižnično-informacijskom su- stavu}

U okviru zajedničkog sustava Nacionalna i sveučilišna knjižnica pruža uslugu edukacije knjižničara svih članica. Tečajevi podijeljeni na osnovne i napredne održavaju se jednom do dvaput godišnje, ovisno o pokazanom interesu. Predavači su redaktori, ključni i sistemski knjižničari Nacionalne i sveučilišne knjižnice. Osnovni tečajevi pružaju uvid u osnove rada u programskim modulima, a namijenjeni su početnicima u radu s knjižničnim programom Aleph. Godišnji program sadrži sedam osnovnih tečajeva. Cilj naprednih tečajeva jest usvajanje znanja o novim ili složenijim funkcionalnostima knjižničnog programa Aleph te specifičnim procesima rada. Napredni tečajevi, četiri godišnja programa edukacije, namijenjeni su iskusnim korisnicima knjižničnog programa Aleph.

\footnotetext{
48 Rezultati provedene ankete dostupni su na Funkcionalno testiranje Alepha. [citirano: 2018-0322]. Dostupno na: http://iks.nsk.hr/fta.

49 Mrežni portal. Nav. djelo.

${ }^{50}$ Usp. Machala, D. Analiza. Nav. djelo.
} 
Ključni knjižničari za modul Katalogizacija drže edukaciju za rad u programskim modulima knjižničnog programa Aleph pod nazivom Osnove funkcionalnog rada u modulu Katalogizacija u okviru kojeg se prolazi kroz:

- Otvaranje modula katalogizacije. Sučelje u modulu (okna, trake, graničnici). Glavna kartica: Kartica zapisa ili katalogizacije, Vrste zapisa (bibliografski, normativni, zapisi o posjedovanju, administrativni)

- Pristup zapisima (pretraživanjem, izravnim unosom)

- Kartica pretraživanja (pretraži, pregledaj, prikaži): čvor Pretraži, čvor Pregledaj

- Otvaranje zapisa: Lokalno pohranjeni zapisi, Zapisi pohranjeni na poslužitelju

- Izrada zapisa: Izrada zapisa postupkom novog zapisa, Izrada zapisa proširenjem iz predloška

- Postupak pretraživanja i unosa pristupnica u bibliografski zapis

- Pohrana zapisa (lokalno i na poslužitelj)

- Pregled zapisa u radnom sučelju i na webu

- Veze u Alephu

- Vježbe iz pretraživanja zapisa, izrade zapisa pomoću novog zapisa i predložaka, pohrane zapisa, izrada zapisa za omeđenu jedinicu građe, za omeđenu jedinicu građe u više dijelova, izrada zapisa gornje razine, izrada zapisa donje razine, izrada zapisa koji je dio numerirane i nenumerirane nakladničke cjeline. ${ }^{51}$

Osim programa redovne edukacije koji je fokusiran na rad u modulu katalogizacije, ključni knjižničari sudjeluju i u demonstracijskim vježbama, također namijenjenim svim članicama u sustavu, s ciljem utvrđivanja zajedničkih procedura rada, pravilne primjene formata MARC 21 za svu vrstu građe i vođenjem aktivne rasprave o svim otvorenim pitanjima vezanim uz rad i donošenje prijedloga za razvoj integriranog knjižničnog sustava. Od velike je važnosti da što više knjižničara sudjeluje u demonstracijskim vježbama kako bi se informirali o promjenama u načinu rada, iako se sve nove odluke prosljeđuju članicama u sustavu. Primjerice prilikom uvođenja nekog novog radnog procesa održavaju se vježbe kako bi se rješavanjem praktičnih problema te poticanjem šire i konstruktivnije rasprave vezane uz zahtjeve sustavnog redakcijskog nadzora nad bazama, adekvatnom primjenom formata i pravila izbjegle pogreške te postigao ujednačen rad.

${ }^{51}$ Integrirani knjižnični sustav. Edukacija. [citirano: 2018-03-22]. Dostupno na: http://iks.nsk. hr/edukacija/. 


\section{Procedura brisanja bibliografskih zapisa}

Ključni knjižničari, uz sistemske knjižničare, redaktore i/ili koordinatore radnih procesa, imaju ovlasti brisanja zapisa u bibliografskoj bazi. Sistemski knjižničari podešavaju razinu ovlasti pojedinih profila za sve sudionike u bazama NSK i ZAG. Radi zaštite i očuvanja sigurnosti podataka u sustavu važno je da svaki jedinstveni broj zapisa za brisanje prolazi definiranu proceduru. Zaprimljeni zapis treba provjeriti i utvrditi točan razlog brisanja (dupliciranje, pogrešno napravljeni zapisi i sl.), ispisati ga i arhivirati, obrisati zapise za primjerke koji su vezani na zapis o posjedovanju, zatim obrisati zapis o posjedovanju, administrativni zapis i naposljetku odabrani bibliografski zapis. Ukoliko postoje dva ista bibliografska zapisa, a svaki je povezan sa zapisom o posjedovanju koji ima različitu signaturu, građa se provjerava te se, ukoliko se radi o identičnoj jedinici, jedan bibliografski zapis briše, a njegov zapis o posjedovanju veže se na onaj bibliografski zapis koji je ostao. Opisana procedura radi se u suradnji s Odjelom nabave.

\section{Suradnja s Radnom grupom za MARC 21}

Radna grupa za format MARC 21 (RG MARC 21) prati razvoj i primjenu bibliografskog formata. Jedan je od zadataka grupe i izrada analize primjene formata MARC 21 u sustavu te izrada plana primjene novih verzija formata. Rad grupe važan je i u segmentu planiranja razvoja skupnog kataloga te njegova proširenja novim članicama, kao i planiranja konverzije ili mapiranja podataka iz drugog bibliografskog formata (UNIMARC) u sustav skupnog kataloga. Članovi su radne grupe knjižničari Nacionalne i sveučilišne knjižnice koji imaju dugogodišnje iskustvo u praćenju formata MARC 21 i radu s različitim vrstama knjižnične građe, a u rad grupe uključeni su i ključni knjižničari.

Kada RG MARC 21 donese neku novu odluku, nakon sustavnog nadzora nad podacima, primjenom formata i nacionalnog kataložnog pravilnika, ona se šalje Povjerenstvu za informacijski sustav na konačnu verifikaciju. Sistemski knjižničari zaduženi su za implementaciju tih promjena u programu Aleph, a svi oni koji rade u samom programu, odnosno formatu MARC 21, dužni su ih primjenjivati od trenutka objave. Primjena novih odluka u procesu svakodnevnog rada koje su RG MARC 21 i Povjerenstvo usvojili može se prikazati u okviru programa Demonstracijskih vježbi.

\section{Zaključak}

Pojam ključnog knjižničara relativno je nov u hrvatskoj knjižničnoj praksi. Člankom se željelo ukazati na ulogu i značaj ključnih knjižničara u okviru integriranog knjižničnog sustava Nacionalne i sveučilišne knjižnice u Zagrebu te knjižni- 
ca iz sustava znanosti i visokog obrazovanja, s posebnim naglaskom na njihovim zadaćama u okviru modula Katalogizacija. Značaj ključnih knjižničara dobrim dijelom proizlazi iz činjenice da predstavljaju sponu između samog knjižničnog rada i informatičko-tehničke podrške bez koje je danas knjižničarstvo nezamislivo. Osim kontinuiranog nadzora nad radom i funkcionalnostima sustava, brige za ujednačenu kataložnu praksu i ispravan način korištenja bibliografskog formata, važan aspekt uloge ključnog knjižničara jest i edukacija korisnika integriranog knjižničnog sustava te međusobna komunikacija svih sudionika radnih procesa.

\section{LITERATURA:}

Aleph: integrated library system. [citirano: 2018-03-22]. Dostupno na: https://www. exlibrisgroup.com/products/aleph-integrated-library-system/.

Buzina, T.; K. Holub. Mrežna građa [Elektronička građa]: upute za katalogizaciju prema formatu MARC 21, Bibliografski podaci, izdanje 1999., 12. verzija dopuna. Zagreb: Nacionalna i sveučilišna knjižnica, 2011.

Digitalni akademski arhivi i repozitoriji. [citirano: 2018-04-10]. Dostupno na: https:// dabar.srce.hr/.

Fu. P.; J. Carmen. Migration to Alma/Primo: a case study of Central Washington University. // Chinese Librarianship: an International Electronic Journal 40(2015). [citirano: 2018-11-25]. Dostupno na: http://www.iclc.us/cliej/cl40FC.pdf.

Fu, P.; M. Fitzgerald. A comparative analysis of the effect of the integrated library sistem on staffing models in academic libraries. // Information Technology \& Libraries 32, 3(2013), 47-58. [citirano: 2018-11-25]. Dostupno na: https://ejournals.bc.edu/ojs/ index.php/ital/article/view/3388.

Funkcionalno testiranje Alepha. [citirano: 2018-03-22]. Dostupno na: http://iks.nsk.hr/ fta.nkcionalno testiranje Alepha. [citirano: 2018-03-22]. Dostupno na: http:/iks.nsk. $\mathrm{hr} / \mathrm{fta}$.

Hodak, V.;D. Blažević. Omeđene publikacije, integrirajuća građa i nakladničke cjeline [Elektronička građa]: priručnik za katalogizaciju u bibliografskom formatu MARC 21. Zagreb: Nacionalna i sveučilišna knjižnica, 2011.

Integrirani knjižnični sustav. [citirano: 2018-03-22]. Dostupno na: http:/iks.nsk.hr/.

Integrirani knjižnični sustav. Dokumenti. [citirano: 2018-03-22]. Dostupno na: http:// iks.nsk.hr/dokumenti/.

Integrirani knjižnični sustav. Edukacija. [citirano: 2018-03-22]. Dostupno na: http://iks. nsk.hr/edukacija/. 
Izvješće o radu za 2016. godinu. Zagreb: Nacionalna i sveučilišna knjižnica, 2017. [citirano: 2018-03-19]. Dostupno na: http://www.nsk.hr/wp-content/uploads/2017/07/ Izvje\%C5\%A1\%C4\%87e-o-radu-NSK-za-2016.-godinu.pdf.

Knjžnični katalog / Nacionalna i sveučilišna knjižnica u Zagrebu. [citirano: 2018-0410]. Dostupno na: http://katalog.nsk.hr/.

Knjižnični katalog / Sveučilište u Zagrebu. [citirano: 2018-04-10]. Dostupno na: http:// zag.nsk.hr.

Machala, D. Analiza korištenja i prihvaćanja Integriranog knjižničnog sustava Nacionalne i sveučilišne knjižnice u Zagrebu te visokoškolskih i znanstvenih knjižnica Republike Hrvatske. // Vjesnik bibliotekara Hrvatske 61, 1(2018), 435-467. DOI: https://doi.org/10.30754/vbh.61.1.631.

Machala, D. Hrvatski skupni katalog Nacionalne i sveučilišne knjižnice u Zagrebu te knjižnica iz sustava Znanosti i visokog obrazovanj: problemska pitanja interoperabilnosti. // Vjesnik bibliotekara Hrvatske 59, 1-2(2016), 469-487. DOI: https://doi. org/10.30754/vbh.61.1.636.

Machala, D. Skupni katalog knjižnica iz sustava znanosti i visokoga obrazovanja Republike Hrvatske. // Glas NSK 4, 14(2018), 23-25. Dostupno i na: http://www.nsk.hr/ wp-content/uploads/2018/03/Broj-14-jesen-zima-2017.-Glas@NSK.pdf.

Machala, D.; L. Machala. Implementacija integriranog knjižničnog sustava Aleph u Nacionalnoj i sveučilišnoj knjižnici u Zagrebu i knjižnicama sastavnica Sveučilišta u Zagrebu i znanstvenih instituta: utvrđenja implementacijskog procesa. // Knjižnice: kamo i kako dalje? : zbornik radova / 12. dani specijalnih i visokoškolskih knjižnica, Opatija, 11.-14. svibnja 2011.; uredile Alisa Martek i Elizabeta Rybak Budić. Zagreb: Hrvatsko knjižničarsko društvo, 2013. Str. 330-343.

Machala, L. Integrirani knjižnični sustav Aleph: implementacija na primjerima Sveučilišta u Iowi i visokoškolskih knjižnica u Litvi. // Knjižnice: kamo i kako dalje? : knjižnice i očuvanje kulturne baštine, knjižnice bez granica: digitalni repozitoriji, knjižnični softveri: zbornik radova / 11. dani specijalnih i visokoškolskih knjižnica, Opatija, 1.-4. travnja 2009.; uredile Tamara Krajna i Alisa Martek. Zagreb: Hrvatsko knjižničarsko društvo, 2010. Str. 231-244.

Mihalić, T. Glazbena građa [Elektronička građa]: upute za katalogizaciju u bibliografskom formatu MARC 21. Zagreb: Nacionalna i sveučilišna knjižnica, 2011.

Miletić Drder, M. Kartografska građa [Elektronička građa]: upute za katalogizaciju prema formatu MARC 21, Bibliografski podaci, izdanje 1999., 12. verzija dopuna. Zagreb: Nacionalna i sveučilišna knjižnica, 2011.

Mrežni portal Knjižnični informacijski sustav Nacionalne i sveučilišne knjižnice u Zagrebu - BUKI. [citirano: 2018-03-30]. Dostupno na: http://buki.nsk.hr.

Nacionalni repozitorij disertacija i znanstvenih magistarskih radova. [citirano: 2018-0410]. Dostupno na: https://dr.nsk.hr/. 
Nacionalni repozitorij završnih i diplomskih radova ZIR. [citirano: 2018-04-10]. Dostupno na: https://zir.nsk.hr/.

Odluka o imenovanju ključnih knjižničara. Zagreb, 2016. (Klasa: 080-01/1 6-01/04, ur. broj: 474-13-01-16-2).

Odluka o imenovanju Povjerenstva za knjižnični sustav u NSK. Zagreb, 1015. (Klasa: 650-01/15-01/1, ur. broj: 474-13-01-15-10).

Orešković, M. VuFind - discovery servis otvorena koda kao programsko rješenje za uspostavu nacionalnoga skupnog kataloga knjižnica iz sustava znanosti i visokoga obrazovanja Republike Hrvatske. // Glas NSK 4, 14(2018), 29-31. Dostupno i na: http://www.nsk.hr/wp-content/uploads/2018/03/Broj-14-jesen-zima-2017.-Glas@ NSK.pdf.

Pigac Ljubi, S.; J. Zajec. Tiskane serijske publikacije i druga neomeđena građa [Elektronička građa]: priručnik za katalogizaciju u bibliografskom formatu MARC 21. Zagreb: Nacionalna i sveučilišna knjižnica, 2011.

Pravilnik za opis i pristup građi u arhivima, knjižnicama i muzejima [citirano: 2018-0326]. Dostupno na: http://nkp.nsk.hr/.

Repositories of the National Library of Finland. RecordManager. [citirano: 2018-0329]. Dostupno na: https://github.com/NatLibFi/RecordManager.

Rezultati provedene ankete dostupni su na Funkcionalno testiranje Alepha. [citirano: 2018-03-22]. Dostupno na: http://iks.nsk.hr/fta.

Smjernice za izradu skupnog kataloga Integriranog knjižničnog sustava Nacionalne i sveučilišne knjižnice u Zagrebu, visokoškolskih i znanstvenih knjižnica Republike Hrvatske. Zagreb: Nacionalna i sveučilišna knjižnica, 2016. [citirano: 2018-03-28]. Dostupno na: http://buki.nsk.hr/wp-content/uploads/2017/03/Smjernice-za-izradu-skupnog-kataloga_2016.docx.

Statut Nacionalne i sveučilišne knjižnice u Zagrebu. [citirano: 2018-03-28]. Dostupno na: http://www.nsk.hr/wp-content/uploads/2012/01/Statut-NSK-24_12_2010.pdf.

Strategija Nacionalne i sveučilišne knjižnice u Zagrebu 2016.-2020. Zagreb: Nacionalna i sveučilišna knjižnica, 2016. [2018-03-19]. Dostupno na: http://www.nsk.hr/ wp-content/uploads/2012/01/Strategija-NSK-2016.-2020..pdf.

Verona, E. Pravilnik i priručnik za izradbu abecednih kataloga. Zagreb : Hrvatsko bibliotekarsko društvo, 1970-1983. Dio 1: Odrednice i redalice. 1970.

Verona, E. Pravilnik i priručnik za izradbu abecednih kataloga. Zagreb : Hrvatsko bibliotekarsko društvo, 1983-1986. Dio 1: Odrednice i redalice. 2. izmijenjeno izd. 1986.

VuFind. [citirano: 2018-03-28]. Dostupno na: https://vufind.org/vufind/.

Vujić, M. Pregledni zapisi u formatu MARC 21 [Elektronička građa]: upute za katalogizaciju. Zagreb: Nacionalna i sveučilišna knjižnica, 2011. 
Vukadin, A. Novi pravilnik za katalogizaciju u kontekstu međunarodnih načela i standarda. // Vjesnik bibliotekara Hrvatske 59, 1-2(2016), 49-71. [citirano: 2018-1122]. Dostupno i na: https://www.hkdrustvo.hr/vjesnik-bibliotekara-hrvatske/index. $\mathrm{php} / \mathrm{vbh} / \mathrm{article} / \mathrm{view} / 16$.

Wilson, T. C. Sistemski knjižničar: oblikovanje uloga, definiranje vještina. Zagreb: Hrvatsko knjižničarsko društvo, 2006. 